\title{
The importance of teaching skills in the UK undergraduate medical curriculum
}

This article was published in the following Dove Press journal:

Advances in Medical Education and Practice

21 September 2015

Number of times this article has been viewed

\section{Nikhil Patel \\ David Zargaran}

Imperial College School of Medicine, Imperial College London, South Kensington, London, UK
Correspondence: Nikhil Patel Imperial College School of Medicine, Imperial College London, Exhibition Road, South Kensington, SW7 2AZ, London, UK

Tel +442075895III

Email nikhil.patelI0@imperial.ac.uk

\section{Dear editor}

We read with great interest the letter by Ah-kee et $\mathrm{al}^{1}$ that highlights the importance and the difficulties surrounding the provision of teaching by junior doctors.

As students of Imperial College London, we have experienced the benefits of teaching skills in the curriculum, having received lectures on teaching skills in our preclinical years as well as a dedicated course in our penultimate year. In line with Ah-kee et al's ${ }^{1}$ proposals, we have found that studying adult-learning concepts and a variety of teaching strategies have not only improved our teaching skills, but also helped guide our own learning.

A convenience sample of our colleagues at St George's, Barts' and the London and University College London Medical Schools all report having formal teaching skills training. The authors, however, note "a lack of formal teaching training within the undergraduate curriculum" and subsequent work could be done to further identify the variations in the provision of training in teaching skills.

However, we fully support the authors' call to improve the skills of undergraduates as teachers. One such method would be to introduce a teaching skills module to highlight the most effective ways to teach others: using a series of lectures, tutorials, and practical sessions. We believe that the most benefit will be gained by students running their own "mini-tutorials" to enhance their own teaching skills, first by teaching a topic outside of academia that interests them to a group of colleagues, and then moving on to topics from the medical curriculum.

The seminal work by the psychologist George Miller has led to the oft cited "Miller's Pyramid" that presents a framework for assessing the different levels of competence in the clinical context. ${ }^{2}$ The ultimate aim of moving from "knowing" to "doing", which is the apex of "Miller's Pyramid", is to achieve competence. This forms the bedrock upon which Peer Assisted Learning flourishes by making the behavioral aspect of "showing and doing" mandatory for teachers. This is fully consistent with the age-old pedagogy of medical apprenticeship, which has enabled generations of doctors to be trained effectively and will no doubt effectively train the future generations "See one, do one, teach one".

\section{Disclosure}

The authors report no conflicts of interest in this communication. 


\section{References}

1. Ah-Kee EY, Scott RA, Shafi A, Khan AA. How can junior doctors become more effective teachers? Adv Med Educ Pract. 2015;6:487-488.
2. Miller GE. The assessment of clinical skills/competence/performance. Acad Med. 1990;65(9 Suppl):S63-S67.

Dove Medical Press encourages responsible, free and frank academic debate. The content of the Advances in Medical Education and Practice 'letters to the editor' section does not necessarily represent the views of Dove Medical Press, its officers, agents, employees, related entities or the Advances in Medical Education and Practice editors. While all reasonable steps have been taken to confirm the content of each letter, Dove Medical Press accepts no liability in respect of the content of any letter, nor is it responsible for the content and accuracy of any letter to the editor.

Advances in Medical Education and Practice

Dovepress

\section{Publish your work in this journal}

Advances in Medical Education and Practice is an international, peerreviewed, open access journal that aims to present and publish research on Medical Education covering medical, dental, nursing and allied health care professional education. The journal covers undergraduate education, postgraduate training and continuing medical education including emerging trends and innovative models linking education, research, and health care services. The manuscript management system is completely online and includes a very quick and fair peer-review system. Visit http://www.dovepress.com/testimonials.php to read real quotes from published authors.

Submit your manuscript here: http://www.dovepress.com/advances-in-medical-education-and-practice-journal 